\title{
PENDIDIKAN AKHLAK ANAK
}

Sebuah Tawaran Pendidikan di Pesantren Studi Analisis atas Kitab

Simțu al-'Iqyān Syaraḥ Bugyah al-Ikhwān Wariyāḍah al-Ṣibyān Karya Abdullāh Bin Aḥmad Bāsaudān

Muhamad Rofingi

SDN 1 Linggapura Lampung

¿muhammadrofingi24@gmail.com

\begin{abstract}
Abstrak
Penelitian ini berawal dari asumsi penulis tentang menurunnya moral anak, yang dipengaruhi oleh buruknya arus globalisasi dan meningkatnya ilmu teknologi yang belum menjadi landasan akhlak mulia. Oleh karena itu, penelitian ini memberikan tawaran kajian pendidikan akhlak anak baik di sekolah maupun di pesantren melalui pemikiran pendidikan akhlak anak yang terdapat dalam kitab Simtu al-'Iqyān Syaraḥ Bugyah al-Ikhwān Wariyāḍah al-Ṣibyān Karya Abdullāh Bin Ahmad Bāsaudān. Jenis penelitian ini adalah library research dengan memakai pendekatan hermeunetik. Pengumpulan data dilakukan dengan cara dokumentasi. Analisis data memakai Content analysis. Adapun hasil dari penelitian ini adalah pendekatan yang dilakukan di dalam kitab simtu al-iqyan tidak hanya secara kognitif, tetapi juga secara afektif yang menekankan pada aspek spiritual. Sehingga anak tidak hanya pintar secara kognitif tetapi juga secara intuitif.
\end{abstract}

Kata kunci: Pendidikan Akhlak Anak, Simtu al-'Iqyān, Pendidikan di Pesantren, Pendidikan akhlak

\section{Abstract}

This research begins with the author's assumption about the decline of children's morals, which is influenced by the bad currents of globalization and the increase in science and technology which has not become the basis of noble character. Therefore, this study offers a study of children's moral education both at school and in Islamic boarding schools through the thoughts of children's moral education contained in the book Simtu al-'Iqyān Syarah Bugyah al-Ikhwān Wariyāụah al-Ṣibyān by Abdullāh Bin Aḥmad Bāsaudān. This type of research is library research using a hermeneutic approach. Data collection is done by means of documentation. Data analysis uses Content analysis. The results of this study are the approach taken in the simtu al-iqyan book not only cognitively, but also affective which emphasizes the spiritual aspect. So that children are not only smart cognitively but also intuitively.

Keywords: Moral education, children's character education, education in Islamic boarding schools

\section{Pengantar}

Secara sekilas, fenomena kemerosotan moral di negara yang mayoritas penduduknya muslim ini masih cukup nampak jelas. Berkembangnya ilmu pengetahuan dan teknologi (IPTEK) yang semakin canggih sehingga dampak 
negatif yang ditimbulkan berpengaruh pada perilaku anak, sehingga perilaku yang tidak bermoral pun terjadi. Indikator-indikator itu dapat diamati di dalam kehidupan sehari-hari seperti; Kekerasan, anak durhaka, suka berbohong, selalu membantah, keras kepala, serta prilaku-prilaku tidak terpuji lainnya, sehingga sifat-sifat terpuji seperti rendah hati, taat, sabar, kejujuran, kesetiaan, kepedulian, saling membantu, kepekaan sosial, tenggang rasa, yang merupakan jati diri bangsa sejak berabad-abad lamanya seolah menjadi barang mahal. (Juwariyah, 2010. 13) Hal ini juga dijelaskan oleh Rifai (Rifa'i et al., 2021) yang menunjukkan bahwa era milenial seperti ini dibutuhkan pendekatan yang tidak hannya intelektual, tetapi juga spiritual dalam mengembangkan potensi setiap manusia.

Adapun faktor-faktor terbesar yang menyebabkan terjadinya kenakalan pada anak adalah berlangsungnya suasana ketidakharmonisan antara ayah dan ibu, kesenggangan waktu yang diberikan untuk anak, lingkungan dan teman yang buruk, perlakuan yang buruk dari orang tua, melihat tayangan film kriminal dan pornografi, banyaknya pengangguran di masyarakat, dan kurang perhatiannya pendidikan orangtua terhadap anak. Faktor-faktor tersebut sangat berpengaruh pada psikologi anak saat mereka bertemu dan berkumpul. Ketika anak membuka matanya kemudian menyaksikan percekcokan yang terjadi di mana-mana maka anak akan lari dari rumah yang dianggap membosankan dan ia pun mencari teman bergaul yang dapat menghilangkan keresahannya. Banyak waktu yang dihabiskan bersama temannya ini, seandainya teman-teman mereka jahat dan nakal, maka secara perlahan anakpun akan terseret ke dalam jurang dekadensi moral dan bahkan akan menjadi sebuah kenakalan yang dapat merusak moral bangsa dan negara. (Abdullāh Nashih 'Ulwān,2015. 75-96)

Kitab Simțul al-Iqyān merupakan karangan ulama besar yang terkenal melihat dari karangan beliau yang begitu banyak dan mayoritas di gunakan sampai saat ini salah satunya kitab qosidah basaudan. Beliau yaitu al-Imām Hujjah Islām Syaikh Abdullāh bin Ahmad bin 'Abdullāh bin Muhammad bin 'Abdurrahmān Bāsaudān, dilahirkan di desa Khuraibeh, Wadi Dau'an, Hadromaut pada tahun 1178 H. Nasab beliau sambung kepada Saȳidina al-Miqdād bin al-Aswad al-Kindi RA. Syaikh Abdullāh Bāsaudān sejak kecil telah diasuh dengan didikan agama dan sejak usia tersebut beliau telah menghafal al-Qur'an dan berbagai matan ilmu. Salah satu guru beliau adalah Syaikh 'Abdullāh bin Aḥmad bin Fāris Baqisi dan Habib Umar bin Abdurrahmān al-Bār murid imām al-Haddād. Beliau juga merupakan pengarang Hadrah Bāsaudān yang terkenal dalam kalang santri. Beliau wafat pada 7 Jumadil Awwal $1266 \mathrm{H}$ dan dimakamkan di kota Khuraibah dengan umur 88 tahun sama dengan umurnya al-Imām 'Abdillāh bin 'Alawi al-Haddād. Dalam kitab inipun banyak sekali mengupas tentang cara-cara mendidik terutama bagi anak dalam hal-hal pokok seperti : Adab terhadap orang tua, menjaga dari makanan yang haram, adab dalam makan dan minum, kewajiban belajar bagi anak ketika sudah tamyı̌z, adab dalam berbicara, perintah untuk rendah hati, meninggalkan sifat țma', adab terhadap saudara dan sahabatnya, dan sebagainya 
dengan menggunakan berbagai metode yaitu metode taḥżir (menakut-nakuti), nasihat, larangan dan uswah, sehingga menjadikan dasar yang positif bagi anak untuk membentengi dari prilaku-prilaku negatif yang ada dalam lingkungan. (Abdullāh bin Ahmad Bāsaudān, 2008. 15-30).

Sejauh pengetahuan peneliti belum ada yang mengangkat judul yang serupa namun banyak karya tema yang berdekatan dengan karya ilmiah yang akan peneliti lakukan. Terdapat enam riset yang sudah dilakukan, yaitu: Pertama, Konsep Pendidikan Akhlak Anak Perspektif Imam Al Ghazali, Eko Setiawan Universitas Brawijaya Malang, (Jurnal Kependidikan, Vol.5 no 1 2017). dalam jurnal tersebut dijelaskan bahwa : Konsep pendidikan akhlak menurut Imam Al Ghazali ialah pendidikan formal dan non formal. Pendidikan non formal dilaksanakan dalam lingkup keluarga, mulai pemeliharaan dan makanan yang dikonsumsi. Sementara untuk pendidikan formal, Imam Al Ghazali mensyaratkan adanya seorang guru yang mempunyai kewajiban, antara lain bertanggung jawab atas keilmuannya dan hendaklah ia membatasi pelajaran menurut pemahaman mereka. Konsep pemikiran Imam Al Ghazali tentang pendidikan akhlak pada anak meliputi akhlak terhadap Allah, akhlak terhadap orang tua, akhlak kepada diri sendiri, dan akhlak kepada orang lain. Adapun akhlak bersumber dari dengan tujuan tertinggi agama dan akhlak ialah mencapai kebahagiaan dunia dan akhirat, kesempurnaan jiwa bagi individu, dan menciptakan kebahagiaan, kemajuan, kekuatan, dan keteguhan bagi masyarakat.

Kedua, Pendidikan Akhlak Menurut Al-Ustadz Umar Baradja Dalam Kitab Akhlaq Li al-Banaiin (Tinjauan Materi dan Metode)". Abu Qosim, Mahasiswa UIN Sunan Kalijaga, Fakultas Tarbiyah, Prodi PAI, 2005. (Abu Qosim, Yogyakarta: 2005). Skripsi ini terdiri dari lima bab dan 96 halaman. Penelitian ini merupakan penelitian kepustakaan (Library Research), dengan mengambil data primer Kitab Akhlaq Lil Banı̆. Metode pengumpulan data yang dilalukan dengan cara mengadakan pengumpulan buku-buku yang berhubungan dengan data primer, wawancara, dan dokumentasi penulis. Adapun analisis data dilakukan dengan memberikan interpretasi terhadap data pokok (primer). Penelitian tersebut lebih menekankan pada kajian data primer dengan mengkaji apa yang terdapat dalam buku akhlakul banain seperti : Pendidikan perspektif Al-ustadz Umar Baraja, akhlak-akhlak terpuji (mahmūdah) dan (mażmümah). Tidak jauh berbeda antara skripsi diatas dengan skripsi yang akan peneliti lakukan, perbedaan diantara keduanya hanyalah terletak pada metode pengumpulan datanya, karena pada skripsi diatas menggunakan dokumentasi, wawancara, sedangkan dalam penelitian ini hanya menggunakan metode dokumentasi dan penafsiran.

Ketiga, Pemikiran Abdullah Nashih 'Ulwan tentang Pendidikan Akhlak Anak (Study Kitab Tarbiyah al-Aulād Fi al-Islām), Salimah Rini, Mahasiswa STIQ An Nur, Fakultas Tarbiyah, Prodi PAI 2007. Jenis penelitian ini adalah penelitian Bibliografi dan kepustakaan dengan metode pengumpulan data dokumentasi dan menggunakan metode analisis data deduktif dan induktif. Skripsi ini terdiri dari lima bab pembahasan dan 96 halaman. Salimah memetakan bahwa ada tiga pokok 
pemikiran Abdullah Nashih Ulwah tentang pendidikan akhlak anak yaitu tanggung jawab pendidikan akhlak, metode pendidikan akhlak anak dan sifat-sifat dasar yang harus dimiliki pendidik. Adapun sifat-sifat yang harus dimiliki bagi seorang pendidik adalah yaitu ikhlas, taqwa, sabar, ilmu, dan rasa tanggung jawab. Sehingga dapat digunakan untuk mencegah dari fenomena-fenomena yang negatif, (Salimah Rini, Yogyakarta, 2007) Skripsi ini dengan skripsi yang akan peneliti lakukan sangatlah berbeda, karena dilihat dari segi jenis, metode dan analisisnyapun berbeda.

Keempat, Urgensitas Pendidikan Akhlak Bagi Anak Usia Dasar (Studi Era Darurat Covid 19). Muhammad Shaleh Assingkily, Miswar (Tazkiya, Vol. IX No.2, Juli-Desember 2020). Penelitian ini termasuk penelitian kualitatif dengan metode studi kepustakaan. Objek kajian terfokus pada analisa buku, artikel ilmiah, dan sumber literasi terkait urgensitas pendidikan akhlak bagi anak usia dasar di era "darurat Covid 19". Analisis data dilakukan dengan mengkaji proses internalisasi akhlak yang diperoleh anak melalui alternatif pembelajaran berbasis e-learning dan upaya penanganan tanggap darurat covid 19. Dalam jurnal tersebut bahwa penanaman akhlak merupakan hal urgen yang patut diberikan sejak usia dasar kepada anak. Sehingga, dalam situasi kedaruratan apapun, termasuk era Covid-19 ini, bangsa tetap mampu melahirkan generasi yang memiliki konsep diri baik sebagai seorang Muslim sejati. Hal ini ditandai dengan upaya pemenuhan tuntutan zaman dengan 4 (empat) aspek yakni (1) pendidikan meng-upgrade kualitas kurikulum, (2) memberikan internalisasi nilai (values), (3) menumbuhkan kesadaran adanya perubahan masa, dan (4) membawa siswa menemukan konsep diri.

Kelima, Konsep Pendidikan Akhlak Pada Anak Menurut Al Qubisi Dalam Buku "Ar Risalah Al- Mufassilah Li Ahwal Al-Muta'alim Wa Ahkami Al-Muta'allimin", Ahmad Labib, UIN Sunan Kalijaga, Fakultas Tarbiah, Prodi PAI, 2011, Skripsi ini terdiri dari empat bab dan berjumlah 80 halaman. Peneltian ini merupakan penelitian kepustakaan (Library Research), pengumpulan data dilakukan dengan menggunakan metode dokumentasi, yaitu melalui benda-benda tertulis berupa buku-buku, dokumen dan internet yang dapat mendukung kajian ini. Adapun analisis yang digunakan adalah model analisis isi (Content Analysis). Labib menyimpulkan bahwa pendidikan akhlak pada anak menurut al-qubisi ini menawarkan bagaimana konsep pendidikan anak-anak, tujuan pendidikan akhlak, kurikulum pendidikan akhlak, metode dan tehnik belajar, dan pendekatan pendidikan akhlak. (Ahmad Labib, Yogyakarta : 2011)

Keenam, Pendidikan Akhlak Anak Usia Dini Di Era Millennial, Dwi Runjani Juwita, Sekolah Tinggi Agama Islam Nahdlatul Ulama (STAINU) Madiun. (At-Tajdid : Jurnal Ilmu Tarbiyah, Vol. 7 No. 2, Juli 2018). Dalam jurnal tersebut dikatakan bahwa pendidikan karakter adalah sebuah proses atau usaha untuk membentuk perilaku peserta didik yang tercermin dalam kata, sikap, perbuatan berdasarkan nilai, norma, dan moral luhur melalui kegiatan bimbingan, pengajaran, dan latihan. Faktor yang mempengaruhi pendidikan akhlak adalah insting, adat/kebiasaan, 
pola dasar bawaan dan lingkungan. Lingkungan ini pun terbagi lagi menjadi beberapa, yakni lingkungan keluarga, sekolah, pendidikan, pekerjaan, jamaah, ekonomi, dan lingkungan pengetahuan. Beberapa hal yang harus dilakukan oleh orang tua atau pun pendidik dalam hal ini adalah memberikan suri tauladan yang baik, membiasakan anak untuk melakukan hal-hal positif, memberikan nasehatnasehat kepada anak, menceritakan kisah-kisah inspiratif serta berlaku adil kepada semua anak.

Dari penelusuran dalam rangka kajian pustaka di atas, penulis menentukan dua rumusan masalah, yaitu pertama, bagaimana Pendidikan Akhlak Anak yang terdapat dalam kitab "Simțu al-'Iqyān Syarah Bugyah al-Ikhwān Wariyāḍah alSibyān" karya Abdullāh bin Aḥmad Bāsaudān? Kedua, apa relevansi Kitab "Simțu al"Iqyān Syaraḥ Bugyah al-Ikhwān Wariyāḍah al-Sibyān" pada pendidikan akhlak anak masa sekarang?

\section{Metode Penelitian}

Metode yang digunakan dalam penelitian ini yaitu metode Content Analysis atau analysis isi. Dasar yang digunakan dalam metode isi adalah dengan penafsiran. Maka dari itu metode ini digunakan dalam dokumen-dokumen yang padat isi dan lebih menekankan bagaimana memaknakan isi komunikasi. (Nyoman Kutha Ratna, 2004. 49). Jenis penelitian ini adalah kepustakaan (library research), yaitu penelitian yang dilakukan di perpustakaan dimana obyek penelitian digali lewat beragam informasi kepustakaan. (Mestika Zed, 2008. 89) Pendekatan yang digunakan dalam penelitian ini adalah dengan hermeneutika. Akar kata hermeunetika berasal dari istilah yunani dari kata kerja hermeneuein yang berati "menafsirkan", dan kata benda hermeneia "interpretasi". (Richard E Palmer, 2016. 14).

\section{Hasil dan pembahasan}

Hasil dan pembahasan ini membahas tentang pentingnya pendidikan anak di dalam kitab simtu al-Iqyan sekaligus tawaran alternatif tentang kajian ini penting untuk dilakukan di pesantren-pesantren.

\subsection{Pendidikan Akhlak Anak dalam Kitab Simțu al-'Iqyān}

Kitab Simțu al-'Iqyān merupakan kitab dasar yang menerangkan tentang perilaku-perilaku yang harus dilakukan seorang pendidik dalam mendidik, supaya anak didiknya menjadi manusia yang terarah dan memiliki akhlak alkarimah. Kitab tersebut terdiri dari lima fashl dan masing-masing fashl terdiri dari beberapa pembahasan.

\section{Definisi Akhlak}

Abdullāh Bāsaudān menyebutkan bahwa akhlak itu diambil dari kata adab, yaitu membersihkan diri terlebih dalam berperilaku yang mulia sehingga menjadikan orang berbudi luhur dan memiliki derajat yang 
mulia, sehingga Abdullāh Bāsaudān menyatakan dalam kitabnya bahwa segala sesuatu perkara yang disangka bagus secara akal, pikiran, maupun perbuatan.

\section{Pengertian Anak}

Anak adalah sebutan atau nama yang digunakan pada seseorang yang baru dilahirkan hingga remaja, Abdullāh Bāsaudān mengatakan dalam dalam kitab Simțu al-'Iqyān disebutkan bahwa :

$$
\text { الصبيان و هو اسم يقع على الولد إلى البلوغ. }
$$

Artinya : Yang dimaksud sibyan merupakan panggilan mulai dari waktu kecil hingga remaja.

Jadi anak hanyalah sebutan atau nama, dan dalam masa ini juga disebut periode perkembangan merentang dari masa bayi hingga menginjak usia remaja (0-12 tahun), dalam ilmu psikologi masa remaja itu berkisar antara usia 13 sampai 22 tahun, masa dewasa berkisar 2345 tahun dan 46-meninggal disebut masa tua. Apabila seoang anak sudah masuk pada usia 12 tahun keatas maka sebutan anak sudah berganti menjadi sebutan remaja. (Agoes Suejanto, 2005. 160)

\section{Pentingnya Pendidikan}

Abdullāh Bāsaudān mengatakan bahwa pendidikan hendaknya dimulai dari kecil, supaya masa depannya terarah. Karena pada masa kecil hati seseorang itu masih kosong dari berbagai macam coretan atau kotoran, sehingga menjadi sangat penting bagi seorang pendidik memulai pendidikan dari masa anak-anak. Pada masa inipula yang akan menentukan masa depannya seorang anak, dalam kitab Simțu al-'Iqyān disebutkan :

$$
\text { لأن نأديب الصبي في صغره زيادة لحظه في كبره. }
$$

Artinya : Karena sesungguhnya pendidikan anak diwaktu kecil itu merupakan tambahan terhadap bagiannya (modal) diwaktu besar.

\subsection{Materi Pendidikan Akhlak Anak}

Materi adalah sebuah bahan atau seperangkat subtansi pembelajaran untuk membantu dalam memaksimalkan kegiatan belajar mengajar. Materi juga dapat dikatakan sebagai informasi atau alat yang diperlukan untuk perencanaan dan penelaah pembelajaran. Dan materi merupakan salah satu yang yang pokok dalam dunia pendidikan sebagai tujuan dalam mendidik peserta didik. Dalam hal ini Peneliti membagi pendidikan akhlak menjadi empat bagian yaitu sebagai berikut: 
1. Akhlak Yang Berhubungan Dengan Allah

1) Taat

Taqwa atau taat artinya takut kepada Allah dengan dasar kesadaran dengan menjalan segala perintah Allah dan menjahui segala larangannya, baik yang sunah maupun wajib sehingga memperoleh balasan dari Allah berupa pahala. Semua orang dimata Allah itu semuanya sama yang membedakan diantara masing-masing adalah ketaqwaannya, semakin taat diri seorang maka semakin tinggi pula derajatnya. Dalam kitab Simțu al-Iqyān disebutkan sebagai berikut :

Taat adalah sesuatu yang dapat menghasilkan kebahagiaan dunia dan akhirat.

2) Menjauhi Tama'

Tama' berati rakus atau arti lain adalah orang yang terlalu cinta dengan dunia sehingga buta dengan hukum halal ataupun haram karena yang di pentingkan hanyalah dirinya sendiri. Dalam kitab Simțu al-Iqyān Abdullāh Bāsaudān menyebutkan bahwasanya tama' adalah marabahaya bagi karakter anak dan suatu perbuatan yang tercela. Sifat tersebut merupakan sifatsifat bagi orang yang lalai dan merupakan dosa yang sangat besar karena berharap sesuatu selain kepada Allah SWT, sebagai berikut :

$$
\text { فإنه أيضا من أعظم الآفات العظيمة و الصفات الذميمة . }
$$

Artinya : Sesungguhnya țama' itu merupakan marabahaya yang sangat besar dan merupakan sifat yang sangat hina.

3) Tawadu

Tawadu adalah rendah hati. Seorang yang memiliki sifat ini oleh Allah akan diangkat derajatnya dimata manusia, sehingga ia akan hidup dalam masyarakat yang damai, tentram dan bahagia. Rendah hati merpakan salah satu sifat-sifatnya para nabi, sehingga orang yang memiliki sifat ini sama derajatnya dengan para nabi. Sebagaimana dalam Simțu alIqyān disebutkan sebagai berikut :

$$
\text { التو اضع أي الخضوع الله تعالى ولجلاله. }
$$

Artinya : Tawaḍu yaitu mendekatkan diri kepada Allah SWT karena keagunganNya

2. Akhlak yang Berhubungan dengan Manusia

1) Menjauhi Pergaulan Bebas 
Faktor besar yang menyebabkan terjadinya kenakalan pada anak adalah kaean yang jahat dan lingkungan yang rusak. Terlebih lagi apabila anak tersebut adalah anak bodoh, lemah akidah, mudah terombang ambing dan cepat terpengaruh ketika bergaul. Oleh karena itu ia akan cepat terpengaruh oleh kebiasaan buruk dan akhlak yang tercela. Abdullāh Bāsaudān mengajarkan kepada kita bahwa dalam memperoleh derajat yang mulia harus berhati-hati dalam bergaul, jangan sampai memilih teman yang buruk supaya tidak masuk kedalam jurang kesesatan.

2) Menghormati Kedua Orangtua

Salah satu kewajiban seorang anak kepada orang tuanya adalah menghormati dan memuliaknnya dengan sebaikbaiknya. Abdullāh Bāsaudān menyebutkan dalam kitab Simțu al-'Iqyān tentang anjuran menghormati kedua orangtua, karena derajat orangtua disisi Allah sangatlah tinggi dan orangtua merupakan wakil Allah di dunia.

3) Adab Berbicara

Abdullāh Bāsaudān mengatakan bahwa untuk menjaga anak supaya tidak banyak bicara, yang dimaksut banyak bicara adalah bicara yang tidak ada manfaatnya atau omongan kosong tanpa ada isinya. Banyak bicara juga sangat tidak disukai dalam konteks agama Islam, karna hal tersebut termasuh salah satu sifatnya orang-orang yang gila dan bodoh. Sebagaimana disebutkan dalam Simțu al-'Iqyān sebagai berikut:

Seorang anak kecil tidak dibolehkan banyak bicara sebab banyak bicara termasuk sifat dari orang-orang gila, disamping itu orang yang banyak bicara banyak salahnya dan pasti akan banyak bohongnya.

4) Akhlak Terpuji

Akhlak mahmūdah atau akhlak terpuji merupakan segala macam bentuk perbuatan, ucapan dan perasaan seseorang yang bisa menambah iman dan mendatangkan pahala.

Mengingat dalam konteks pendidikan anak, nilai karakter yang ditanamkan sangatlah tinggi untuk kepentingan masa depannya, karena karakter seorang itu tercermin bagaimana didikannya ketika kecil. Oleh karena itu penanaman karakter pada anak harus diutamakan dari hal yang lain. Sebagaimana dikatakan oleh Abdullāh Bāsaudān bahwasanya akhlak yang akan diperoleh ketika masa kecilnya secara bertahap akan tersimpan hingga masa remajanya, maka dari itu pembiasaan akhlak mahmūdah dan meninggalkan akhlak yang mażmūmah. 
Sebagaimana disebutkan dalam kitab Simțu al-'Iqyān sebagai berikut :

أنه إذا نشأ الولد مؤدبا بهده الآداب المذكورة وصارت أوقاته وساعاته بها معدورة. كان

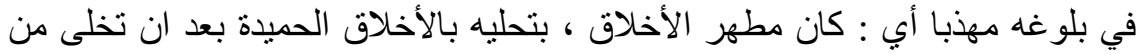

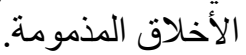

Artinya : Ketika seorang anak tumbuh dengan diajari tatakrama yang sudah disebutkan dan wataknya juga dihiasi dengan adab tersebut, maka dia akan menjadi anak yang berakhlak yang baik ketika remajanya,: (orang yang memiliki akhlak yang bersih disebabkan adanya dia selalu berhias dengan akhlak yang terpuji setelah lolos dari akhlak yang tercela)

3. Akhlak yang Berhubungan dengan Diri Sendiri

1) Sopan Santun

Dalam kegiatan sehari-hari manusia tidak dapat meninggalkan kedua perkara ini, baik dalam hal apapun dan dimanapun. Oleh karena itu sopan santun sangat dibutuhkan dalam akhlak baik makan maupun minum, ataupun lain sebagainya. Abdullāh Bāsaudān dalam kitab Simțu al-'Iqyān mengatakan bahwa adab ketika makan yaitu :

وبعد ما يفطم تجده يشتهي اكل الطعام دائما لا ينتهي يعلموه الأكل باليمين و البسملة حتما

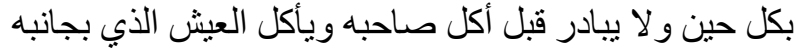

Artinya : Sesudah tidak memakan asi kamu akan menemukan anak menginginkan memakan makanan secara terus menerus dan tidak berhenti-henti, maka ajarkanlah olehmu untuk memakan dengan tangan kanan dan menyebut nama Allah disetiap waktu, dan tidak terburu-buru makan sebelum orang yang memiliki makanan dan makanlah makanan yang sudah tersedia.

2) Menjaga Diri (Iffah)

Haram adalah sesuatu perkara yang dilarang oleh syariat untuk dilakukan, orang yang melanggarnya akan mendapatkan dosa dan hukuman didunia maupun diakhirat. Maka dari itu Abdullāh Bāsaudān melarang mebiasakan anak memakan makanan yang haram karena dalam syariat tidak diperbolehkan dan secara psikologi juga sangat membahayakan bagi fisik maupun psikis anak. Sebagaimana disebutkan dalam kitab Simțu al-Iqyān sebagai berikut:

Ketika air susu mengandung barang haram disebabkan ibu mengkonsumsi barang haram, maka efeknya anak akan 
cenderung dilingkupi melakukan pekerjaan buruk,hal ini dimakruhkan dari segi panca indra dan juga dari segi akal, dan hal tersebut termasuk pekerjaan buruk didalam keyakinan dan sebuah kebohongan dalam berbicara dan sebuah keburukan dalam pekerjaan. Maka pekerjaan jelek ini akan menjadi kebiasaan diawal dan akhir, sebab orang yang memakan makanan yang haram maka seluruh anggota tubuhnya seraca tabiat terkategorikan berbuat maksiat.

3) Zuhud

Zuhud adalah apabila hamba tertimpa musibah dalam kehidupan dunia seperti hilangnya harta, anak, atau selainnya, maka dia lebih senang memperoleh pahala atas hilangnya hal tersebut daripada hal itu tetap berada di sampingnya.

\subsection{Metode Pendidikan Akhlak Anak}

\section{a. Tahżı̆r}

Metode tahżĭr artinya menakut-nakuti anak didiknya dengan hal yang positif, guna menjadikan semangat belajar anak dan membentengi fisik maupun mental anak.

b. Uswah

Metode uswah atau keteladaan berasal dari kata teladan yang artinya perbuatan atau hal lain yang dapat ditiru dan dicontoh. Sebagaimana diungkapkan oleh Al-Ashafahani yang dikutip dalam bukunya Armai Arief, bahwa menurutnya kata al Uswah berati suatu keadaan ketika seorang manusia mengikuti manusia yang lain.

c. Ta'lim

Metode ta'lım merupakan metode dalam pembelajaran yang bertujuan untuk melihat seberapa jauh pemahaman anak didik tentang pelajaran yang disampaikan sehingga ilmu yang diajarkan itu benar-benar masuk pada diri seorang anak.

d. Nasihat (perhatian)

Nasihat merupakan suatu metode pendidikan yang sangat efektif dalam membentuk keimanan anak, akhlak, mental dan sosialnya adalah mendidik dengan nasehat.

e. Larangan

Larangan yaitu melarang peserta didik melakukan sesuatu yang dapat membahayakan dirinya atau sesuatu yang dirasa adalah sesuatu yang negatif.

f. Praktik

Metode praktek merupakan metode pembelajaran yang sangat penting untuk melihat seberapa jauh anak memahami pelajaran dan 
mempraktekkannya, metode ini juga bisa digunakan untuk melatih anak supaya belajar hati-hati.

\subsection{Relevansi Kitab Simțu al-'Iqyān Terhadap Pendidikan Agama Islam Masa Kini}

Dalam hal ini peneliti akan menguraikan relevansi antara isi kitab dengan pendidikan Agama Islam masa kini yaitu sebagai berikut :

\subsubsection{Penekanan Metode Pendidikan dalam Pembentukan Karakter Anak}

Penekanan berarti menguatkan atau meningkatkan, apabila dikaitkan dengan sebuah metode dapat diartikan menggunakan sebuah metode dengan tingkat tinggi atau seoptimalkan mungkin, supaya benar-benar terealisasi dengan baik. Dengan menggunakan sebuah cara atau langkah yang baru, menarik, menantang dan lain sebagainya. Kebanyak metode dalam pendidikan sudah tidaklah asing, namun bagaimana kita mengemas metode tersebut supaya menjadi menarik dan menghasilkan sebuah karya yang berkualitas tinggi.

Dalam pendidikan sebuah penekanan bisa diisyarat sebagai sebuah wadah barang, yang dapat dinilai hanya dengan melihat sisi luarnya, apabila luarnya bagus maka secara tidak langsung akan timbul pemikiran yang positif bahwasanya dalamnya juga bagus, juga sebaliknya. Maka dari itu sebagai pendidik harus kreatif, inivatif dan propesional.

Abdullāh Bāsaudān menjelaskan bahwasanya melatih anak dalam mencapai cita-citanya merupakan sebuah perkara yang sangat penting sebagai bentuk perhatian, keteladanan dan kasihsayang. Disisi lain juga mengisyaratkan bahwasanya dalam mencapai itu semua dibutuhkan sebuah cara, langkah atau syarat supaya masa depanya terarah. Maka dari itu untuk mencapai itu semua tidak lepas dari sebuah metode untuk mempermudah mencapai sebuah tujuan pokok. Dalam kitab Simțu al-Iqyān disebutkan sebagai berikut:

$$
\text { أن رياضة الصبيان وسلوك طريقها والاعتناءبها من أهم الأمور }
$$

Artinya : Sesungguhnya untuk mencapai sebuah tujuan, diperlukan latihan dan perhatian karena hal tersebut merupakan perkara yang sangat penting bagi seorang anak

\subsubsection{Pengokohan Nilai Karakter sebagai Benteng dari Paham-Paham Islam Radikal}

Dekadensi moral yang begitu tinggi sehingga menjadikan tatanan bangsa ini tidak tertata dengan baik, sehingga membutuhkan penguatan guna memperbaiki nilai moral para generasi bangsa. Para pemuda adalah tonggak negara, apabila pondasinya terbuat dari barang murahan maka akan berakibal fatal yang terus-menerus. 
Melihat semakin banyaknya faham yang masuk sehingga semakin besar pula cobaan yang dihadapi para pemuda-pemuda zaman sekarang. Oleh karena itu kunci dari semua ini adalah pada nilai akhlak. Apabila para generasi sudah menjunjung tinggi akhlak mana masa depan bangsa pasti terjamin kenyamananNya.

المر ادبالقيام عليهم : تعليمهم وتعريفهم ما سيأتي و الإعتناء بهم في سائر أحو الهم .

Artinya : Yang dimaksud makna melaksanakan tugas terhadap anak adalah mendidik, mengarahkannya dalam segala bidang, dan mengawasi dalam seluruh perilakunya.

\subsection{Sebuah Tawaran Kajian di Pesantren}

Dari beberapa uraian yang sudah dijelaskan di atas, hemat penulis bahwa kitab simtu al-iqyan ini layak untuk dikembangkan kajiannya di pesantren. Hal ini disebabkan kurangnya referensi pakem yang terdapat di pesantren. Alasan-alasan yang lebih mendalam adalah sebagai berikut:

Pertama, jika dilihat dari sudut pandang relevansi kajian kitab ini menunjukkan bahwa penting untuk menekankan pembentukan karakter anak agar bisa mandiri. Mandiri diartikan secara luas tidak hanya sebatas bisa mengurus dirinya sendiri, tetapi juga kemandirian dalam berpikir. Sehingga kemandirian tersebut bisa menjadi tolok ukur kekuatan dan kemapanan anak, agar tidak mudah terpengaruh oleh perkembangan zaman.

Kedua, nilai-nilai yang terdapat di dalam kitab simtu al-iqyan merupakan nilai yang sangat cocok diterapkan di pesantren. Sebab di pesantren tidak hanya tempat mencari ilmu tetapi juga tempat untuk mendidik karakteristik para santri. Pendidikan karakter semacam ini sangat bergantung pada peran seorang kiai dan pola pendidikan yang sudah tersistem dengan baik.

Kedua hal tersebutlah yang bisa dijadikan sebagai tawaran untuk pengkajian pendidikan moral pada anak. 


\section{Kesimpulan}

Berdasarkan hasil penelitian ini adalah bahwa Pendidikan akhlak anak menurut Abdullah Bāsaudān dalam Kitab "Simtu al-'Iqyān dan relevansinya yaitu : 1). Pengertian akhlak secara umum, materi dan tujuan, pendidik (guru) dan metode pendidikan akhlak anak. Dalam pengertian terdapat makna secara umum dan khusus, dalam materi terdapat pengertian akhlak yang berhubungan Allah (taat, țama' dan tawaḍu'), akhlak yang berhubungan dengan sesama manusia (menjaga pergaulan, menghormati kedua orangtua, adab berbicara, dan akhlak terpuji), akhlak yang berhubungan dengan lingkungan (sosial kemasyarakatan), dan akhlak yang berhubungan dengan diri sendiri (sopan santun, menjagadiri dan zuhud). Metode yang digunakan (tahżìr, uswah, ta'līm, nasihat larangan dan praktik) Relevansi antara isi dari kitab Simtu al-'Iqyān karangan Abdullah Bāsaudān dengan pendidikan akhlak di zaman sekarang sangatlah erat kaitannya terlebih dalam hakikat penanaman nilai karakter pada anak didik dan mencegahan dari pahampaham baru di era modern saat ini. Nilai-nilai pendidikan karakter atau akhlak yang disebutkan di dalamnya pun selaras dengan nilai pendidikan akhlak yang ada di masa sekarang yaitu untuk menumbuhkan generasi muslim yang berakhlākul karĭmah dan bermoral.

\section{Daftar Pustaka}

Juwita, D. (2018). Pendidikan Akhlak Anak Usia Dini di Era Milenial. At-Tajdid: Jurnal Ilmu Tarbiyah, 7(2), 282-314. Retrieved from http://ejournal.inismupacitan.ac.id/index.php/tajdid/article/view/13 $\underline{8}$

Sholehah, B., Wahid, A., \& Muali, C. (2018). Pendidikan Akhlak Perspektif AlGhazali. At-Tajdid: Jurnal Ilmu Tarbiyah, 7(2), 190-205. Retrieved from http://ejournal.inismupacitan.ac.id/index.php/tajdid/article/view/13 $\underline{3}$

Bāsaudān, Abdullah Bin Ahmad. Simtu al-Iqyān Libanon: Darul Minhaj, 2008

Setiawan, Eko (2017) Konsep Pendidikan Akhlak Anak Menurut Imam Ghazali.

Jurnal Kependidikan, vol 5 no 1, 2017

https://doi.org/10.24090/ik.v5i1.1252

Juwariyah, Dasar-Dasar Pendidikan Anak Dalam Al Qur'an Yogyakarta: Teras, 2010 Labib, Ahmad. Konsep Pendidikan Akhlak Pada Anak Menurut Al Qubisi Dalam Buku "Ar Risalah Al- Mufassilah Li Ahwal Al-Muta'alim Wa Ahkami AlMuta'allimin" (Yogyakarta: Skripsi Fakultas Tarbiyah PAI, Uin Sunan Kalijaga, 2011)

Nashih 'Ulwān, Abdullāh. Tarbiyah al-Aulād Fŭ al-Islām Terj. Arif Rahman Hakim, Sukoharjo: Al Andalus, 2015 
Palmer, Richard E (2016). Hermeunetika "Teori Baru Mengenai Interpretasi" Yogyakarta: Pustaka Pelajar

Qosim, Abu Pendidikan Akhlak Menurut Al-Ustadz Umar Baraja Dalam Kitab Akhlaq Lil Banain (Yogyakarta: Skripsi Fakultas Tarbiyah PAI, UIN Sunan Kalijaga, 2005)

Ratna, Nyoman Kutha. Teori Metode dan Tenik Penelitian Sastra Yogyakarta: Pustaka Pelajar, 2004

Rifa'i, M. R., Kurniawan, R. A., \& Pramono, B. (2021). THE FORMATION OF INTELLECTUAL AND SPIRITUAL INTELLIGENCE OF STUDENTS IN THE ERA OF ADVANCED SCIENCE AND TECHNOLOGY WITH T2R INNOVATION. JURNAL TARBIYAH, 27(2). https://doi.org/10.30829/TAR.V27I2.744

Rini, Salimah. Pemikiran Abdullah Nashih Ulwah Tentang Pendidikan Akhlak Anak Study Kitab Tarbiyatul Al-Aulad Fi Al-Islam (Yogyakarta: Skripsi Fakultas Tarbiyah, Prodi PAI STIQ An Nur, 2007)

Suejanto, Agoes. Psikologi Perkembangan Jakarta: Rineka Cipta, 2005

Zed, Mestika. Metode Penelitian Kepustakaan Jakarta: Yayasan Obor Indonesia, 2008 